This item was submitted to Loughborough's Research Repository by the author.

Items in Figshare are protected by copyright, with all rights reserved, unless otherwise indicated.

\title{
Chinese multinational enterprises in Europe and Africa: How do they perceive political risk?
}

\section{PLEASE CITE THE PUBLISHED VERSION}

https://doi.org/10.1007/s11575-017-0331-1

\section{PUBLISHER}

(C) Springer Verlag

\section{VERSION}

AM (Accepted Manuscript)

\section{PUBLISHER STATEMENT}

This work is made available according to the conditions of the Creative Commons Attribution-NonCommercialNoDerivatives 4.0 International (CC BY-NC-ND 4.0) licence. Full details of this licence are available at: https://creativecommons.org/licenses/by-nc-nd/4.0/

\section{LICENCE}

CC BY-NC-ND 4.0

\section{REPOSITORY RECORD}

Han, Xia, Xiaohui Liu, Lan Gao, and Pervez Ghauri. 2019. "Chinese Multinational Enterprises in Europe and Africa: How Do They Perceive Political Risk?”. figshare. https://hdl.handle.net/2134/26408. 
Chinese Multinational Enterprises in Europe and Africa:

How do They Perceive Political Risk?

\author{
Xia Han ${ }^{a}$ \\ ${ }^{\text {a }}$ Coventry Business School \\ Coventry University \\ CV1 5FB \\ Xiaohui Liu ${ }^{\mathrm{b} * \mathrm{c}}$ \\ Lan Gao ${ }^{b}$ \\ b School of Business and Economics \\ Loughborough University \\ Leicestershire, LE11 3TU \\ c School of International Business \\ Southwestern University of Finance and Economics \\ Chengdu, China \\ Pervez Ghauri ${ }^{\mathrm{d}}$

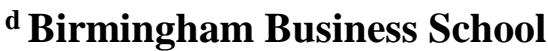 \\ University of Birmingham \\ Birmingham, B15 2TY
}

*Corresponding author.Email: x.liu2@lboro.ac.uk 


\title{
Chinese Multinational Enterprises in Europe and Africa:
}

\section{How do They Perceive Political Risk?}

\begin{abstract}
The concept of political risk has been defined from the perspective of developed-country multinational enterprises (MNEs) and has mainly focused on the political and regulatory perils in developing host countries. However, we have limited understanding of how emerging market firms perceive political risk in international marketplaces. Adopting a case study method, we examine how Chinese MNEs perceive political risk when operating in developed and developing host countries, specifically, the European Union (EU) and Africa. Our findings show that Chinese MNEs regard their home-country origin and industry-specific restrictions as major political risks in the EU. By contrast, they consider the volatile political environment in some African countries as the main source of political risk. In addition to the sharp contrast in the political and regulatory environment between the EU and African states, Chinese MNEs commonly encounter political risks in both markets due to their own behaviour.
\end{abstract}

Keywords: Political risk; Chinese MNEs; the European Union; Africa 


\section{INTRODUCTION}

Outward foreign direct investment (FDI) by emerging economy multinational enterprises (EEMNEs) has become one of the most researched topics in international business (IB). The political risk faced by EEMNEs in international marketplaces has also received increasing attention. Extant research has commonly defined political risk as the unexpected change of the 'rules of the game' by host-country governments that can adversely affect business operations (Butler and Joaquin 1998; Casson and Lopes 2013). While this line of enquiry has generated insights regarding how EEMNEs respond to and manage host-country political risk (Buckley et al. 2007; Liu et al. 2016), extant research implicitly assumes that political risk is universal, and EEMNEs face the same types of political risk as developed-country MNEs (DMNEs). Thus, our knowledge about how political risk is conceived from the viewpoint of these new players remains limited.

Existing literature in this field can be divided into two streams. The first stream of research looks at the impact of political risk on EEMNEs when venturing into other developing host countries. Drawing on conceptual models of DMNEs, this stream of research assumes that these new players are tempted by, and show greater competitiveness, in risker political environments (Cuervo-Cazurra and Genc 2008). A second, small but growing stream of research concerns EEMNEs expanding into more advanced economies. Although these countries are renowned for their well-established market systems and institutions, this does not imply that firms operating in these contexts are shielded from changing external circumstances (Bremmer 2014). However, extant literature has mainly applied the established concept of political risk based on DMNEs. Little attention has been devoted to the fundamental issues of how EEMNEs perceive political risk in overseas marketplaces, given substantial home-government involvement in their international activities (Peng 2012). Thus, this study explicitly examines the question as to how EEMNEs perceive political risk when operating in diverse institutional environments, including developed and developing host countries

To address the above research question, we adopt a qualitative case study approach to examine the political risk perceived by Chinese MNEs operating in the EU and in African countries. While much has been reported about the political obstacles faced by Chinese MNEs in international marketplaces (Globerman and Shapiro 2009; Liu et al. 2016), the EU as the world largest single market, and Africa as an increasingly important economic power, have not been thoroughly investigated. Therefore, our research focuses on these two regions.

This study makes several contributions to the literature on political risk in IB. First, we depart from existing studies which assume that political risks faced by EEMNEs are consistent with traditional definitions drawn 
from the experience of DMNEs by systematically unpacking the concept of political risk from EEMNEs' perspective (Liu et al. 2016; Quer et al. 2012). Second, taking Chinese MNEs’ FDI as our research object, we find that the political risks faced by these new players are multidimensional and rooted in a number of home country, host country, industry and firm-behaviour sources. This finding is in stark contrast to the traditional conceptualization of political risk which has mainly focused on the host-country environment and industry characteristics. Third, by comparing Chinese MNEs’ perceived political risks in different institutional settings, we find that the perception varies depending on the external institutional environment. In more developed European market settings, the country-of-origin, EU industrial regulations, and Chinese firms' own behaviour are the main sources of political risk, while in the less developed African markets, political risks are rooted in host-country conditions and firms' own behaviour. Thus, our study suggests that the boundaries of political risk perceived by EEMNEs are much broader than those based on DMNEs.

\section{LITERATURE REVIEW}

\section{What is Risk?}

While scholars have generally recognized the critical role of risk in affecting MNEs' international operations, little agreement has been reached with regard to the conceptualization and scope of risk (Buckley 2016; Liesch et al. 2011). Extant literature has offered various definitions. One stream of research uses a statistical probability approach to define risk as the quantifiable probability that events will occur and influence business operations (Knight 1921; Liesch et al. 2011). The other looks at the potential loss vis-à-vis the potential gain of a decision, and frames risk as the negative variation in business outcomes (March and Shapira 1987). Yet, another group of researchers focuses on the unknowability of the external environment and defines risk as significant contingencies that reduce performance predictability (Miller 1992; 2007).

Confusion about the notion of risk goes further as research has often used the terms, risk and uncertainty, in an interchangeable manner (Buckley et al. 2016). Some studies have treated risk and uncertainty as a composite variable and label them as synonymous (Alvarez and Barney 2005). This has resulted in misconceptions about their roles in IB as risk and uncertainty are related but distinct concepts (McKelvie et al. 2011). While both can arise from firms' external environments, their underlying assumptions and their impact on MNEs' international operations are different (Buckley 2016).

Under Knight’s (1921) statistical metaphor, risk refers to a set of possible outcomes, and the likelihood of each occurring can be calculated, whilst uncertainty refers to outcomes where the likelihood of each taking place is 
unknown. Yet, this approach has been challenged due to its neglect of the role of decision makers (Miller 2007). Hence, the emphasis of human judgement in the decision-making process has given rise to research that distinguishes risk and uncertainty by drawing on transactional cost economics (TCE). Studies anchored within TCE assume that decision-makers are bounded-rational, and the lack of information makes them hesitate to make decisions or act under uncertain situations (Buckley and Carter 2004; Williamson 1985).

Additionally, another group of researchers drawing on the real option (RO) theory assumes that decision-makers are rational and risk-averse, thus being able to choose among a set of future states with relevant information (Billitteri et al. 2013). It has been suggested that decision-makers are not strictly rational since they are bounded by cognitive limitations, but it does not imply that they are irrational (Miller 2007; Payne et al. 1993). Rather, when decision-makers have accumulated more information they can convert some uncertainties to risk, hence allowing them to make decisions and take action (Sarasvathy 2001). This evolving view of managerial rationality is a key step which can help bridge the existing research on risk and uncertainty, drawing on the seemingly contradictory TCE and RO perspectives. Hence, the conversion from uncertainty to risk may be moderated by the possession of information (Buckley 2016). When there is more information available, firms can make investment decisions. Thus, it may be more appropriate to conceive of uncertainty as a general environmental phenomenon, whilst risk is investor and investment specific (Liesch et al. 2011; March and Shapira 1987). As Friedmann and Kim (1988) suggested, risk cannot exist without the presence of an organizational entity or activity in a host country, but uncertainty as an environmental character can. This corresponds to Kobrin’s (1979) argument that research on political risk in MNEs' international operations should focus on the impact of political events upon firms rather than the events per se. Thus, in this study we follow previous research (Casson and Lopes 2013; Friedmann and Kim 1988) by focusing exclusively on political risk.

\section{What is Political Risk?}

Although the term 'political risk' appears frequently in the literature, agreement about its definition remains limited (Darendeli and Hill 2016; Kobrin 1979). The literature can be generally divided into two groups. The first group assumes an adversarial relationship between the government and business (Alon and Herbert 2009). Research built upon this assumption has offered a variety of definitions. For example, political risk has been defined as host government interference with MNEs' operations (Butler and Joaquin 1998), as constraints imposed on firms from specific countries or industries (Desbordes 2010; Robock 1971), and as discontinuities occurring in the business environment due to political changes (Fitzpatrick 1983). 
More recent literature tends to assume a co-operative relationship between MNEs and host-country governments by underscoring the potential for mutual gain (Darendeli and Hill 2016; Jiménez et al. 2015), as political interference in MNEs' operations, tempted by short-term gains, may jeopardize the government's own objectives, such as economic growth generated as a result of FDI (Luo 2001). This group of researchers suggests that perceived political risk by MNEs depends on whether their business objectives are consistent with the host government's long-term political, economic and social agendas (Stevens et al. 2015). Firms may perceive a lower degree of political risk when their activities are more aligned with the government's long-term goals (Henisz and Zelner 2005). Thus, this strand of research regards political risk as a complex and multidimensional phenomenon that may arise from a variety of host- and home-country sources (Click 2012; Stevens et al. 2015). MNEs are not only affected by governmental actions and political changes in host countries, but are also increasingly under scrutiny from host-country stakeholders regarding, for example, whether they acknowledge their corporate social responsibilities towards natural environmental protection, sustainable development and fair treatment for local employees (Scherer et al. 2013).

\section{Conceptualization of Political Risk}

While research on the role of political risk in MNEs' international success has progressed, its conceptualization and theoretical boundaries remain a fragmented and narrowly defined area (Jakobsen 2010). This section focuses on how political risk has been conceptualized when MNEs operate in heterogeneous institutional and industrial contexts.

Institutional boundary of political risk for DMNEs and EEMNES

Initial research has used the above mentioned definitions to capture how political risks are perceived by DMNEs. Several conceptual frameworks have been proposed to examine the political perils faced by American, European and Japanese MNEs. Simon (1984) noted that political risk in a host country depends on its stage of institutional and economic development. MNEs tend to face non-violent political risks, such as unfavourable legal rulings and stringent entry requirements, in countries with well-established socio-political and economic systems (Bremmer 2014; Simon 1984). By contrast, more severe risks, such as the overthrown of political regimes, wars, and expropriations are likely to occur in host countries with an underdeveloped socio-political and economic environment (Casson and Lopes 2013). Jensen (2008) maintained that MNEs investing in developing countries with democratic regimes tend to face a lower degree of political risk and are less likely to experience expropriation and political violence risks. Drawing from the political science literature, Desbordes (2010) 
proposed that hostile political relations between home and host countries may impose political obstacles on MNEs' overseas operations.

In addition, the rapid growth of FDI conducted by EEMNEs has stimulated research to analyse how these new players perceive political risk in overseas markets (Buckley et al. 2007; Liu et al. 2016). This newer stream of research suggests that the types of political risk faced by EEMNEs tend to be more heterogeneous than those of DMNEs (Satyanand 2010). A number of studies have found that EEMNEs are not discouraged, but show a greater willingness to expand into risky environments (Buckley et al., 2007; Cuervo-Cazurra and Genc 2008; Liu et al., 2016). By contrast, for those expanding into developed countries, EEMNEs tend to face stringent government investigation and political opposition (Bremmer 2014; Globerman and Shaprio 2009). Moreover, such hurdles are more intensive for state-owned enterprises (SOEs) than private firms (Cui and Jiang 2012; Meyer et al. 2014). A significant portion of these risks arise from EEMNEs' country-of-origin (Globerman and Shapiro 2009), which has been largely overlooked in the existing literature (Moeller et al. 2013). Yet the adoption of conceptual frameworks based on DMNEs' experience may lead researchers to oversimplify the way that political risks are perceived by EEMNEs. As the rapid internationalisation of EEMNEs may challenge the existing theories of internationalisation (Liu et al. 2005), it is important to reconceptualize political risk from the perspective of these new players.

Industrial boundaries of political risk for DMNEs and EEMNEs

Political risk can be experienced either by all firms of an entire country or by those from selected countries, industries, or those undertaking specific activities (Robock 1971). While extant literature has yielded insights into the political risks associated with the host-country’s macro environment, research on industry-related political risks is still at an early stage (Alon and Herbert 2009). Existing studies have examined DMNEs operating in key regulated industries such as extraction, petroleum, banking, telecommunications and utilities and reported that these industries are subject to greater government intervention than those more liberalized industries with fewer restrictions, and thus exposed those MNEs to a higher degree of political risk (Bonardi et al. 2006). Yaprak and Sheldon (1984) showed that MNEs operating in natural resources and financial service industries experienced a higher degree of political risk than those in technologically dynamic industries. Jakobsen (2010) found that in the global aluminium industry, substantial political risks are present in developing host countries despite their welcoming attitude to FDI. Despite previous research showing that operating in key regulated industries may have important political implications (Bremmer 2014), an in-depth examination of how such industry-related political risks are perceived by EEMNEs is absent. 


\section{RESEARCH CONTEXT AND METHODOLOGY}

We employ the qualitative case study method to explore Chinese MNEs’ perception of political risks when operating in the EU and African countries. Our objective is to (1) enrich the understanding of political risk from the perspective of EEMNEs and (2) delineate the boundary conditions of perceived political risk by EEMNEs in different institutional and industrial contexts. Qualitative exploratory research is particularly effective in opening the 'black box' of what lies behind the phenomenon and helping to answer the how and why questions (Doz 2011: 583). In particular, the use of qualitative data enables us to better understand the neglected aspects of risk perception by EEMNEs, thus helping us to draw new theoretical insights, and systematically reconceptualize the notion of political risk based on the experience of EEMNEs.

\section{Sampling}

Following Yin (2003), two criteria have been used to select the sample firms and interviewees. First, the length of internationalization should be sufficient for us to collect meaningful information on firms' perception of political risk. Therefore, we selected firms with an overseas presence of at least five years to allow us to explore the issues related to political risk that they have encountered (Gao et al. 2015). Second, the interviewees need to be familiar with their companies' international strategies and operations. Thus, those who worked at the international investment department of the corporate headquarters, or were responsible for international operations, were considered to be the most appropriate participants. Our unit of analysis is individual Chinese firms that operate in the EU and African countries. These two markets are our research contexts which enable us to compare and contrast the perceptions of political risk of the sample firms.

Potential companies were approached through the authors' personal networks. Initial communication with the interviewees was made to explain the nature of this study, with the promise of anonymity. We included a variety of firms with different ownership forms (SOEs vs. private-owned firms), various lengths of international experience and different industries in order to capture the variations in perceived political risks by these firms. Eighteen companies agreed to participate in our study. We then checked their suitability and excluded two operating outside the EU or Africa. As a result, our sample consisted of sixteen companies that have an established presence in the EU and/or African countries. Detailed characteristics of our sample companies are presented in Table 1.

Insert Table 1 about here 


\section{Data Collection}

Reconceptualizing political risk requires the consideration of a multitude of factors (Alon and Herbert 2009).

Hence, our interview guide was structured around the broad theme of how Chinese MNEs perceive political risk in their overseas operations. Based on five pilot interviews with industrial experts, we revised the interview guide in order to avoid inappropriate questions. Semi-structured interviews were carried out to encourage the interviewees to provide their opinions regarding the questions.

We conducted two rounds of interviews from October 2014 to April 2016 to safeguard the reliability of our data. The first round included sixteen face-to-face interviews. At the end of these interviews, we asked the interviewees to introduce colleagues who could also participate in this research. A total of eleven interviewees provided their colleagues' contact information and those people were interviewed in the second round. In total, we conducted twenty seven interviews. The interviews were conducted in Mandarin (24) and English (3) and were recorded. The length of interviews varied from fifty minutes to three and a half hours. All interviews were transcribed within 24 hours to minimize information loss. We also collected archival data from multiple sources, including corporation websites, television interviews and newspapers. In addition, we contacted government agencies and professional associations, such as the Industrial Development Authority in Ireland and the Chinese General Chamber of Commerce in Africa to enquire about specific investment policies. These data complement the information from our interviews and facilitate an in-depth understanding of the political risks faced by our sample firms in overseas markets.

\section{Data Analysis}

We started by coding and analysing each interview transcript, i.e. within-case analysis. As we were interested in comparing Chinese MNEs in European and African markets, transcripts were classified into two groups according to their host region. For companies having a presence in both, we coded their European and African operations separately. Within-case analysis was followed by cross-case analysis that aimed at classifying emerging categories.

Each interview transcript was studied for similarities and differences (Glaser and Strauss 1967). We merged similar codes into the same first-order category and continued coding the transcripts in this manner until no further distinct or shared patterns could be detected. Alongside developing first-order categories, we identified linkages among these categories that could lead to the development of more theoretically-oriented second-order themes. We then distilled the second-order themes into more aggregated dimensions, which enabled us to understand how Chinese MNEs view political risk at country, industry and firm level. 
Figures 1a and 1b provide an overview of our data structure. As we coded Chinese MNEs operating in the EU and African countries in two groups, a three-step process in data analysis was used in each group (Gioia et al. 2013). As shown in Figure 1a, for Chinese MNEs operating in the EU, we identified thirteen categories in the first-order analysis. In the second-order codes, we identified six themes. We then distilled these themes into three theoretical dimensions: home-country sourced political risks, industry-sourced political risks, and firmbehaviour sourced political risks. Figure 1b reported the types of political risk encountered by Chinese MNEs in African countries. We identified nine categories in the first-order analysis, while the second-order codes were classified into four themes. Finally, we aggregated these themes into two theoretical dimensions: host-country sourced political risks and firm-behaviour sourced political risks.

Insert Fig 1a and Fig 1b about here

\section{FINDINGS}

Political risks perceived by Chinese MNEs in their European and African operations can arise at country, industry, and firm-behaviour levels. At the country level, the evidence reveals that Chinese MNEs perceive political risks differently in European and African markets. While the more stable institutional environment in the EU has presented MNEs with opportunities, the 'baggage' that Chinese MNEs carry from home has subjected them to subtler and more implicit home-country sourced political risks. By contrast, the volatile institutional context in Africa has exposed Chinese MNEs to more drastic political changes, and hence the political risks that they face have tended to arise from the underdeveloped political and regulatory environment in the host country. The industrial context can have important implications for Chinese MNEs' venturing into the European market. Chinese MNEs operating in more regulated sectors face a wider array of rules imposed by the host country and the EU than those in more liberalized industries. At firm level, a common type of political risk faced by Chinese MNEs in overseas markets largely resulted from their own inappropriate behaviour.

\section{Home-country Sourced Political Risks in the EU}

Our findings revealed that differences in ideologies, concerns over national security, and competition for economic dominance can put Chinese MNEs under political pressure even when expanding into developed countries where well-established market institutions provide a sound environment. The 'hand' of the homecountry government can travel abroad with its MNEs and acts as a political barrier to firms’ overseas expansion. For Chinese MNEs venturing into the EU, their home-country origin was considered by our interviewees to be a major source of political risk, impeding their firms’ overseas operations. Such home-country sourced political 
risks mainly result from potential threats to the host-country’s national security as perceived by the host-country government, and the unfair advantages conferred by the home-country government.

Threats to the host-country's national security

The evidence reveals that host government concerns over the national security of strategic assets, ongoing competition for economic dominance, and different political ideologies have made Chinese MNEs subject to substantial political and regulatory screening. The view of our interviewees was that host governments were concerned about losing strategic resources and technologies to Chinese competitors, which in turn could undermine their country’s economic security and competitiveness. For example, the demand for high-quality food products has prompted Chinese MNEs to enter the European dairy sector. This has posed significant threats to the availability of some dairy products for European consumers and thus has led some EU member states to introduce additional purchase quotas and regulatory screening for acquisitions proposed by Chinese companies. Similarly, the capability of reverse engineering and economies of scale possessed by Chinese MNEs allow them to enter the European market at lower costs. This represents a critical threat to the host-country’s competitiveness. Hence, stricter regulations on Chinese MNEs have been introduced by the EU to secure their technological assets.

"European (country) governments are very suspicious to us. They do not want to waive these industries into to the hands of Chinese firms because they do not want to see customers or products from China occupy their market.” (Firm O, Interviewee O1)

Moreover, the free market economy is the dominant economic ideology in the EU where most business transactions are shaped by market-based mechanisms. It is therefore difficult for the policymakers of these countries to accept the excessive involvement of the Chinese government in business activities when that involvement could harm free-market competition. As our interviewees reflected, the appointment of government officials and the heavy involvement of the Chinese government in FDI projects are likely to result in barriers to Chinese investment being approved by the host government.

"When we met the mayor of XXX (a French city), we were asked by a French official about whether our project needs to be approved by the Chinese government and whether there will be Chinese officials sitting on the executive board.... As you know, Western countries are sensitive to, and very averse about political involvement in commercial activities." (Firm O, Interviewee O2) 
In addition, Chinese MNEs are perceived to be linked to China's national objectives and interests. They are considered not only as commercial entities, but also as carriers of home-government political missions. This has made the EU member states wary of Chinese MNEs as they may pose threats to host countries by spreading competing political ideologies. Many interviewees suggested that the competing political ideologies between European countries and China have resulted in greater political resistance with regard to Chinese MNEs in the belief that they represent the Chinese government.

"When we conduct business in European countries, some of their governments are very cautious because they think that the Chinese government stands behind us.” (Firm C, Interviewee C1)

This is especially salient with regard to Chinese SOEs, which are more likely to cause EU government concerns and political opposition than their private counterparts. This has largely resulted from Chinese SOEs' closer affiliation with their home government.

“We can access the European market but merely doing property investment. We cannot bid for infrastructure or national security-related projects in these countries. Their (EU members) governments will not allow Chinese companies, especially SOEs, to enter these industries because they are concerned about our political intentions and links with the communist party at home.” (Firm M, Interviewee M2)

\section{Unfair competition}

In addition to concerns over national security, Chinese MNEs' access to funds provided by the home-country government has been a controversial issue as it is considered an unfair advantage for Chinese MNEs. Such access to financial support at home has been perceived by the host-country government to harm market competition. Thus, it could trigger host-government speculation regarding capital offered by the Chinese government, which in turn could become a source of political risk. Home-government subsidies and cheap loans are deemed a key source of unfair advantage that can distort market competition within the EU. It is well known that the ambition of establishing world-class MNEs has prompted the Chinese government to offer subsidies to boost Chinese MNEs’ competitiveness so that their products can be sold at lower prices in overseas markets. However, the subsidies violate the EU competition rules and put other companies at a greater competitive disadvantage. Several cases have been filed by the European Commission (EC) targeting Chinese products and firms that are subsidized by the Chinese government. As our interviewee explained, anti-subsidy investigations launched by the EC represent an important political obstacle that has discouraged them for further investment. 
"We would like to expand our investments in Europe. But the anti-subsidy case filed by the EC has discouraged us and made us feel very uncomfortable.” (Firm E, Archive)

Additionally, the financial market imperfections in China enable Chinese MNEs to access cheap finance that reduce their costs. Chinese policy banks have launched low-interest loans and export credit schemes to foster the competitiveness of Chinese high-tech, electronic, and equipment firms. Such cheap funds have been perceived as unfair competition and against free-market competition. A number of our interviewees indicated that the EU host-country governments tended to be suspicious of their companies' source of funds. Cheap finance from the home government thus constitutes a home-country sourced political risk faced by Chinese MNEs in Europe.

“Abundant capital provision from China is not an absolute advantage but a drawback sometimes. We have been asked by the French government to explain whether we have got cheap loans from China. Some governments in the EU are very cautious that Chinese firms' cheap capital access can damage the market order and put other firms in a disadvantaged position.” (Firm O, Interviewee O2)

\section{Host-country Sourced Political Risks in African Countries}

Chinese MNEs were prompted by the opportunities presented in African countries, such as first-mover advantages and less sophisticated consumer demands. However, the volatile political environments within and across some African states have imposed daunting challenges on Chinese MNEs. Our evidence shows that radical conflicts at national and regional levels have been Chinese MNEs’ major sources of political concern.

Volatile political environment in the host country

The changing political regimes in some countries can cause social unrest, thus put foreign MNEs’ personnel and asset safety at greater risk. In almost all of our interviews, a change of political regime is considered to be a critical issue for Chinese MNEs operating in Africa. Several interviewees reflected that their firms were reluctant to undertake investment initiatives in countries where governments were unstable, primarily due to security concerns.

“For Africa, our main worry is still about risk and associated safety issues of our personnel, financial and nonfinancial assets. There are nearly 400,000 Chinese people in Angola. If a civil war takes place, it would be impossible to evacuate all of our workers.” (Firm M, Interviewee M1).

The volatile political and regulatory environment in the host country can also take the form of a poorly enforced legal framework that subjects Chinese MNEs to inconsistent interpretations of investment regulations. The weakly enforced regulatory frameworks in some African countries have exposed Chinese MNEs to risks, such 
as a breach of contract by the host government and discretionary legal enforcement by local judiciary bodies. Many of our interviewees indicated that their African operations have been subject to the cancellation of payments and discretionary interpretations of regulations by the host-country government.

"The police and judiciary in Sudan have great discretion, and are very tough towards foreign companies. Various fees and fines can be levied on us for different reasons whenever they want.” (Firm P, Interviewee P2). Regional conflicts

Beside a generally volatile political environment within the host country, conflicts at interstate and regional levels are regarded by our interviewees as another source of political risk when venturing into Africa. Political shocks, such as the outbreak of interstate wars and territorial disputes, have led Chinese MNEs to suffer significant loss.

"The separation of North Sudan and South Sudan has caused wars at the border and territorial disputes. Many of our construction sites were located in South Sudan, but now we cannot go back.” (Firm P, Interviewee P2)

The spillover of socio-democratic conflicts at the regional level can result in greater volatilities across neighbouring states that in turn can expose Chinese MNEs to political risk, and disrupt their operations. One example that was repeatedly pinpointed by our interviewees was the spread of the 'Arab Spring' across the region of North Africa. The socio-political movement has reshaped the political environment of the region. The overthrow of political regimes and associated social unrest that took place simultaneously in several countries have seriously affected the proper functioning of market institutions. As a result, such regional-wide political shocks have exposed Chinese MNEs’ operations to extensive risks.

"We have seen a major deterioration of the social and political environment in North Africa in recent years. Riots during the 'Arab Spring' in 2011 affected our exports to other countries in the region.” (Firm I, Interviewee I1)

\section{Industry-sourced Political Risks in the EU}

Despite the progress in global market liberalization, industrial regulations and restrictions remain in place to oversee MNEs' activities in most countries. While such restrictions can potentially affect the operations of all sectors, their impact on the 'key industries', including telecommunications, utilities, pharmaceuticals, healthcare, energy and financial services are particularly salient (García-Canal and Guillén 2008) as these industries are heavily regulated by the government. As a result, the demand and supply of goods and services in these 
industries can be influenced by government policies such as product safety rules, entry requirements, and capacity control. Thus, the industrial sectors in which MNEs operate can have important implications for firms' perceived risk in overseas markets. Evidence from our interviews indicates that Chinese MNEs operating in more liberalized industries hold very different views from those operating in more regulated industries in the EU.

\section{Regulated industries}

The European single market act came into force in the 1980s and resulted in a number of industries being regulated at the regional level to ensure internal market prosperit . For MNEs seeking opportunities in some of the abovementioned regulated sectors, restrictions have been levied at both market entry and operational levels. At market entry level, rules of entry, product testing requirements and the conversion of industrial standards have been imposed by the EC and other relevant authorities to regulate investment from outside the EU. The evidence reveals that such restrictions have resulted in Chinese MNEs having to face more complicated registration issues, which in themselves represent an important form of market entry barrier. For example, the herbal medicine sector has been regulated by the EC regarding product testing standards and registration procedures since 2004. Yet, the sophisticated procedures of registration have made Chinese pharmaceutical firms subject to greater market entry barriers and obliged them to incur much higher costs in order to market their products.

"The registration process for herbal medicines is extremely complex in the EU and we have to pay huge fees to test our products. Maybe the testing procedures are feasible for medicines from Western countries because there is normally only one single ingredient in their products. But for Chinese medicines there are often multiple ingredients and we have to pay testing fees for each one. This is unaffordable for us." (Firm N, Interviewee N1) Restrictions can also be imposed at the operational level to regulate business activities. For Chinese MNEs, the enforcement of output limits has made them subject to a higher degree of political intervention. A well-known example was the milk quota restriction that was introduced in 1980s which aimed to regulate competition within the European dairy sector. The milk quota system was still in place at the time of our interviews. As one interviewee noted, the output quantity restrictions imposed by the EU authority constituted a key political obstacle to their expansion in the European dairy industry.

"Our plant in Ireland is limited by the EU milk quota restrictions. Once we exceed the quota, there will be a risk of fines. So, we only keep one production line in Europe." (Firm G, Interviewee G1) 


\section{Liberalized industries}

In the past few decades, de-regulation has taken place in most industries in the EU and has resulted in reduced regulatory barriers and simplified administrative procedures. For Chinese MNEs operating in more liberalized industries characterized by fewer regulatory restrictions and policy interventions, the well-established industry infrastructure has provided them with a sound environment which has facilitated these firms' operations in the EU.

“Our businesses are in real estate and entertainment. These are consumption industries. There aren't many policy restrictions from the UK or other European country governments." (Firm F, Interviewee F1)

Furthermore, the enforcement of the Single Market Act, which promotes the free movement of goods and services, has provided an open ground for firms to compete within the EU. The open market established by the Single Market Act is regarded as an important advantage by the majority of the interviewees. As one interviewee explained, the Single Market Act has facilitated their company's access to a greater consumer base across the EU member states at much lower risk.

"We manufacture our products in Ireland and can export to other EU states without worrying about tax or tariff because of the free movement in the EU." (Firm H, Interviewee H1)

\section{Firm-behaviour Sourced Political Risks in Both Markets}

Despite the stark contrast in institutional environments between the EU and African states, our evidence revealed that the inappropriate behaviour of a small number of Chinese MNEs, such as ignorance of sustainable development, a lack of respect towards the local culture and hostile industrial relations, can trigger adverse local responses, thus exposing all Chinese MNEs to political risks in both markets. As our interviewees regularly pointed out, such inappropriate practices and behaviour have led to negative attitudes towards some Chinese MNEs by the host government and the general public.

\section{Negative local government attitude}

A lack of professional training can lead some Chinese MNEs to run the risk of violating local employment acts, and engaging in unethical conduct. Such inappropriate behaviour can lead to a poor opinion of all Chinese MNEs in the eyes of the local government, which could be followed by more stringent regulatory treatment on all Chinese MNEs investing in the local market. For example, tense industrial relations with local employees experienced by Chinese MNEs in both European and African markets can result in legal disputes. This may undermine the host government's intention of attracting Chinese investment in order to generate greater 
economic prosperity and employment opportunities. The host government may come to view Chinese MNEs as exploiting the local labour force rather than contributing to economic growth, especially in African countries. Such a negative attitude may lead to a stricter regulatory environment in which Chinese MNEs' operate.

"Managing industrial relations is critical because it can drag us into trouble with the French government if we cannot get along with the local employees. For example, we had a problem of paying pensions to local staff and it almost took us to the court. This can potentially damage our image with the French government and result in more regulations imposed on our business." (Firm O, Interviewee O2)

"Injuries and accidents at our construction sites can make the Rwandan government think that Chinese companies do not care about protecting the local workers. They would certainly view this very unfavourably." (Firm L, Interviewee L2)

The weakly enforced regulatory framework in China has provided some Chinese MNEs with opportunities to exploit institutional voids and get away with unethical behaviour. However, such conduct is not tolerated by governments in the EU and African countries. As a result, tougher and sometimes dyadic-specific treatments have targeted unethical business practices which can form a critical source of political risk faced by all Chinese MNEs.

"The degree of enforcement of the EC Act (Directive on Herbal Medicinal Products) varies in different member states...In some countries like the UK and Netherlands, the governments did not introduce many restrictions. But a number of counterfeits were found to be supplied by firms from China. They used toxic ingredients and caused serious side effects. After these scandals were reported, the UK government imposed stricter rules to regulate herbal medicines." (Firm $N$, Interviewee N1)

"There are many Chinese construction workers in Africa and they have a lot of troubles due to their behaviour. So the biggest issue that we have now is to get working visas for our workers because many African country governments have implemented a quota system to restrict the number of Chinese workers, which has caused problem with our operations there." (Firm M, Interviewee M1)

Negative local public attitude

The disregard of local history, culture and religious rituals has frequently been mentioned by the interviewees as a critical issue that has caused Chinese MNEs trouble in European and African markets. Such ignorance can make the local public view these firms as socially irresponsible, hence damage the overall image of Chinese 
MNEs and result in the boycotting of Chinese products. Political activities can be organised by local interested parties to influence their government's attitude against Chinese MNEs' operations. As one of the interviewees from Firm F explained, negligence of the host-country's history and culture by a small number of Chinese MNEs can lead to local public aversion. As a result, they may lobby the government to impose stricter regulations on all Chinese MNEs or protest against their operations.

"Our company has not realized the importance of having good public relations in Europe, so the locals tend to see us as disrespectful to their culture which can cause problems. The local public have voting power, so their attitude towards us to a great extent can influence their government's attitude especially at the time of a general election. When the locals do not like us, they can lobby the government to suspend our operations. The government would also view us more negatively and treat our operations unfavourably." (Firm F, Interviewee F2)

"There were some Chinese businessmen who disregarded the local culture and religious rituals, which gave the locals a very bad impression and caused negative feedback towards all Chinese firms. Some local stakeholders have already attempted to persuade their government to put stricter controls on us.” (Firm I, Interviewee I1)

Furthermore, a lack of attention to local economic development by some Chinese MNEs, as well as the loss of business opportunities and profits by the locals, have triggered adverse responses from the local interested public, and thus caused social disapproval of Chinese MNEs. As a result, the host-government's sensitivity towards Chinese MNEs' inappropriate conduct may be augmented by these local interested parties.

"Overall, the relationship between our company and the local African people has become increasingly unfavourable. In countries like Tanzania, the locals are very hostile to us because they cannot gain from doing business with us. They think that the Chinese have taken all the profits away from them." (Firm L, Interviewee L2)

The lack of protection over intellectual property rights at home has provided some Chinese MNEs with the incentive to produce and sell counterfeit products. However, when expanding into overseas markets, the adoption of home-country practices can harm their reputation and cause greater distrust of their products among the local public. Such inappropriate practices lead to a negative view of Chinese companies by the host-country public. Public sentiments and distrust towards counterfeit products supplied by a small number of Chinese companies can prompt the local consumer associations and media to lobby their government to more carefully 
control all Chinese MNEs’ operations by introducing new legislation or stricter requirements on Chinese products. This has occurred in both markets.

"Selling counterfeit products by a few Chinese firms have damaged the reputation of Chinese medicines and the European consumers do not trust us anymore. A number of new regulations have been introduced in the Netherlands to inspect medicines from China after those scandals had been reported.” (Firm N, Interviewee N1)

“There were some Chinese businessmen who sold counterfeit products to African consumers. So now we are not trusted by the locals and it has brought us many problems from their government.” (Firm M, Interviewee M1)

\section{DISCUSSION}

This study focuses on the political risk faced by Chinese MNEs when expanding into the EU and Africa. We find that their perceived political risks are country, industry and firm-behaviour related. Such risks are more complex than those encountered by DMNEs. This highlights the importance of unpacking the notion of political risk from the perspective of EEMNEs. In this section, we draw on the findings from our multiple case studies to discuss the way that Chinese MNEs perceive political risk and derive propositions accordingly.

\section{Propositions}

Home-country sourced political risks

While the existing literature on political risk tends to focus on host-country factors, the rise in EEMNEs has challenged this conventional wisdom (Satyanand 2010). Since MNEs cannot always separate themselves from the image and influence of their home country when expanding abroad (Click 2012), it is important to take into account the impact of country-of-origin on the political risks faced by EEMNEs in foreign marketplaces. The country-of-origin, or home-country origin, refers to 'the country where the corporate headquarters of the company marketing the product or brand is located' (Johansson et al. 1985:391) and host-country governments are likely to react to the country-of-origin of MNEs (Stevens et al. 2015). Host-country governments may encourage MNEs from certain countries as they bring desirable resources; equally, they may be wary of other nationalities due to potential threats to a host-country's national security and competitiveness (Cuervo-Cazurra 2011). Thus, the home-country origin of EEMNEs can have critical implications for the way that they are perceived by the governments of both developed and developing countries.

Our findings complement extant research by revealing that Chinese MNEs’ perceived political risks in the EU tend to originate from their home-country origin as they are treated as representatives of their home country 
(Desbordes 2010). Concerns over national security that result from political resistance and competing economic interests can make the host government seek to ring-fence their national strategic assets from Chinese investment. Furthermore, access to home-country government financial support can lead host government to fear the unfair competition associated with investment by Chinese MNEs. Such concerns have resulted in extra scrutiny from the EU member governments. Hence, Chinese MNEs are exposed to risks caused by their ‘Chinese’ label, representing a critical source of political risk in developed countries.

Additionally, the evidence shows that political scrutiny has been more intensively exercised by host-country governments in the EU on Chinese SOEs than private firms due to their close affiliation with the Chinese government. This is consistent with Globerman and Shapiro’s (2009) observation that Chinese SOEs are more likely to face government speculation in the U.S. than their private counterparts. This reinforces the view that SOEs not only serve the economic purpose, but more importantly, the ideological purpose of projecting their home-government political and economic influence in overseas markets (Cuervo-Cazurra et al. 2014).

Proposition 1: Chinese MNEs are likely to encounter political risks when a host-country government perceives them as posing potential threats to national security and competitiveness.

\section{Host-country sourced political risks}

Despite the increasing integration of global economic activities, the volatile political environment remains a critical concern that inhibits economic efficiency and national competitiveness in the developing world (Jakobsen 2010). The frequently changing political regimes and the weak legal framework in some developing countries can lead to the deterioration of living standards and loss of life. Moreover, regional political turbulence can profoundly disrupt social and economic activities. As a result, MNEs operating in these markets tend to face severe political turmoil and inconsistent regulatory treatment which can jeopardize their operations (Darendeli and Hill 2016).

Our findings explicitly show that Chinese MNEs’ perceived political risks in African markets mainly result from exogenous political shocks and events. Such turmoil at domestic and regional levels represents a significant political challenge and can undermine their operational confidence. The findings are consistent with the view that host-country political volatilities tend to be a top concern for MNEs from both advanced and developing countries (Satyanand 2010). This concern may be explained by the traditional bargaining mechanism which suggests that the host-government’s bargaining power tends to increase vis-à-vis MNEs once the latter’s capital is sunk in the host country (Jakobsen 2010). The authoritarian political environment and discretionary 
policymaking process in some African states have enabled Chinese MNEs to negotiate favourable terms before their entry. Yet, they have tended to underestimate the costs when the 'rules of the game' in the host country are changed at the post-entry stage (García-Canal and Guillén 2008). Our study suggests that Chinese MNEs at the post-entry stage mainly perceive political risk in Africa as stemming from the volatile political environment in the host country and the region. This shows that Chinese MNEs' perceptions of political risk in Africa are similar to DMNEs (Casson and Lopes 2013). Thus, the traditional way of conceptualizing political risk by focusing on the deficiencies of a developing host-country's political and regulatory environment is still relevant to EEMNEs operating in such a country.

Proposition 2: Chinese MNEs are likely to encounter political risks in a developing host country with a volatile political environment and regional conflict.

\section{Industry-sourced political risks}

During the last few decades, technological changes and the reduction of trade barriers in most parts of the world have encouraged MNEs from virtually all industries to participate in international competition. However, such global economic integration does not replace the importance of national governments in regulating industrial policies and business activities. Industry-related regulations are still enacted by national governments to supervise and sometimes intervene in business operations. The impact of such policy interventions is particularly striking for MNEs operating in regulated industries (Holburn and Zelner 2010). Hence, industryrelated regulations levied by the host-country government represent a key source of political risk for foreign MNEs (García-Canal and Guillén 2008).

Our findings revealed that the enforcement of industrial policies by the EU can be a mixed blessing for Chinese MNEs. On the positive side, several waves of de-regulation by the EU member states have allowed Chinese MNEs to compete on more equal terms within the EU. On the other hand, those operating in regulated industries are subject to restrictions imposed at the regional level which has resulted in greater entry barriers and operational complexities. It is recognized that MNEs in highly regulated industries require greater research attention (Holburn and Zelner 2010). Yet, extant literature has mainly focused on DMNEs expanding into the regulated industries of developing host countries (Bremmer 2014). The implication of industry-related political risks for EEMNEs has received scant attention. Our findings help to fill this gap by showing that industrial restrictions imposed by the EU can substantially affect Chinese MNEs' expansion into those regulated industries. Thus, our findings not only confirm that the traditional conceptualization of industry-related political risks still 
apply to Chinese MNEs, but also highlight the role of regional institutions in regulating foreign investment activities.

Proposition 3: Chinese MNEs operating in more regulated industries are likely to encounter a higher degree of industry-sourced political risks than in more liberalized industries.

\section{Firm-behaviour sourced political risks}

Extant literature has stressed that the different levels of economic development between developed and developing countries have created contrasting environments, and hence different political risks for MNEs to deal with (Jakobsen 2010). A more nuanced aspect of political risk that stems from firms’ own behaviour has been under-explored. Our findings indicate that by importing unsuitable home-country practices, Chinese MNEs have commonly experienced firm-behaviour related political risks regardless of the stage of economic development of the host countries. While Chinese MNEs are prompted by the opportunities presented in European and African markets, inappropriate or self-destructive behaviour by a few Chinese firms may drag them into hostile relations with the host government. They may be perceived as failing to deliver their promise of boosting local economic growth, thus making their presence less legitimate in the eyes of the government (Stevens et al. 2015). The failure to achieve legitimacy, i.e. aligning business objectives with the political and economic agenda of the host-country government, can motivate the latter to intervene in business activities (Henisz and Zelner 2005). Specifically, unacceptable conduct by a small number of Chinese MNEs can prompt the local government to take political and regulatory actions. In other words, when firms are deemed to be untrustworthy with regard to self-regulation, the host-country government can impose rules in order to maintain market order and regulate firms' behaviour. This has become an extra layer of political risk faced by Chinese MNEs in both developed and developing countries.

Our findings further suggest that the host-country government's evaluation of MNEs can be reinforced by the attitude of the public. As the government consists of individual policymakers and branches (Zelner et al. 2009), these constituents may constantly interact with other interested stakeholders, including consumers, political parties and media (Stevens et al. 2015). Hence, the way that these social groups and actors perceive Chinese MNEs can subsequently influence government and policymakers. Ignorance of the local norms by Chinese MNEs can undermine their social approval. Such unfavourable responses from the local interested parties can exert a powerful influence over government decisions through lobbying and demonstrations. As a result, the 
political risks faced by Chinese MNEs are heightened through the interplay between the government and the public.

Proposition 4: Chinese MNEs are likely to encounter political risks when the government and public in a host country are critical of their behaviour.

\section{Contributions}

By highlighting the heterogeneous types of political risk encountered by EEMNEs in international marketplaces, our research advances IB literature in three main ways. First, this study departs from mainstream research and challenges the assumption that political risks are exogenous and result from a host-country's volatile political environment. Our findings show that political risk can arise endogenously from MNEs' home-country identity and firms' own inappropriate behaviour. Thus, our research contributes to extant literature by revealing the theoretical importance for reconceptualising political risk from the perspective of EEMNEs.

Second, focusing on Chinese MNEs operating in the EU and African countries, we find that these new players tend to encounter more subtle and complex political risks than DMNEs which are grounded in a wide array of home and host country, industry and firm-behaviour sources. This enriches the existing research on political risk which overly focuses on the volatilities of a host-country's political environment or industry characteristics. Thus, our reconceptualization of political risk provides a more complete understanding of its multidimensional nature and complex components.

Third, by examining Chinese MNEs operating in developed and developing countries, we find that the boundary of political risk from the viewpoint of Chinese MNEs is dynamic, and varies with the external institutional environment. In the institutionally more stable and economically more advanced European market, Chinese MNEs' perceived political risks are rooted in their home-country origin and regional industrial regulations. By contrast, they tend to perceive more traditional host-country sourced political risks in less-developed African markets. Some Chinese MNEs' inappropriate practices represent a common concern that can lead these new players to encounter political obstacles in both markets. Thus, our study shows that the boundary of political risk analysis should be expanded to reflect the perspective of EEMNEs.

\section{Implications}

Our study has a number of policy and managerial implications. First, host-country governments' concerns about their national security and the financial support granted to Chinese MNEs by the Chinese government, have 
exposed those companies to home-country sourced political risks when venturing into more advanced economies, like the EU. As Chinese MNEs unavoidably carry the shadow of their home government, the Chinese government should consider providing Chinese MNEs with support in more internationally acceptable ways, such as updated information about a host-country's market trends instead of direct subsidies and/or cheap loans. Second, Chinese MNEs should adopt comprehensive risk assessment strategies when expanding overseas. In developed host countries with well-established market systems, they should consider those implicit aspects of political risk, such as speculation and regulatory restrictions imposed by both the host-country and regional authorities. When operating in a developing host country with a volatile political environment, they need to develop effective risk management strategies, such as purchasing political risk insurance to protect their business interests. Third, Chinese managers should pay attention to their corporate social responsibility and avoid exporting unsuitable behaviour to their overseas operations since inappropriate conduct can lead to adverse attitudes towards Chinese investment by the host-country government and public. Chinese MNEs should invest in public relations and professional training to build a positive image in overseas markets.

\section{Limitations and Future Studies}

This study has several limitations which present avenues for future research. First, based on a sample of Chinese MNEs, we take an initial step to compare the types of political risks that EEMNEs encounter in different institutional settings. Future research could be extended to MNEs from other emerging economies and examine whether they face similar political risks. Second, we only focused on the concept of political risk in this study, but did not consider an equally important and related concept, uncertainty. Future research could explore how EEMNEs perceive and manage uncertainty in different institutional settings. Finally, our study is based on qualitative analysis, thus we are unable to draw any statistical inference regarding whether firm size, age and international experience moderate the perceptions of political risk by EEMNEs. Future studies could test the propositions derived from our study by controlling for these firm characteristics.

\section{CONCLUSION}

This study investigates an under-explored yet fundamental question as to how Chinese MNEs perceive political risk in the EU and Africa, and complements extant research that has largely drawn on conceptual models of DMNEs. Using a qualitative analysis approach, we found that political risks can stem from a set of country, industry and firm-behaviour sources for Chinese MNEs operating in both markets. The findings reveal that the 
way that Chinese MNEs perceive political risk differs from DMNEs. Hence, our study helps develop a more

complete conceptualization of this important factor from EEMNEs’ perspective.

\section{REFERENCES}

Alon, I., \& Herbert, T. T. (2009). A stranger in a strange land: Micro political risk and the multinational firm. Business Horizons, 52(2), 127-137.

Alvarez, S. A., \& Barney, J. B. (2005). How do entrepreneurs organize firms under conditions of uncertainty? Journal of Management, 31(5), 776-793.

Billitteri, C., Nigro, G. L., \& Perrone, G. (2013). How risk influences the choice of governance mode in biopharmaceutical inter-firm relationships. International Business Review, 22(6), 932-950.

Bonardi, J. P., Holburn, G. L., \& Bergh, R. G. V. (2006). Nonmarket strategy performance: Evidence from U.S. electric utilities. Academy of Management Journal, 49(6), 1209-1228.

Bremmer, I. (2014). The new rules of globalization. Harvard Business Review, 92(1), 103-107.

Buckley, P. J. (2016). The contribution of internalisation theory to international business: New realities and unanswered questions. Journal of World Business, 51(1), 74-82.

Buckley, P. J., \& Carter, M. J. (2004). A formal analysis of knowledge combination in multinational enterprises. Journal of International Business Studies, 35(5), 371-384.

Buckley, P.J., Chen, L., Clegg J. \& Voss, H. (2016). Experience and FDI risk-taking: A microfoundational reconceptualization, Journal of International Management, 22(2), 131-146

Buckley, P. J., Clegg, L. J., Cross, A. R., Liu, X., Voss, H., \& Zheng, P. (2007). The determinants of Chinese outward foreign direct investment. Journal of International Business Studies, 38(4), 499-518.

Butler, K. C., \& Joaquin, D. C. (1998). A note on political risk and the required return on foreign direct investment. Journal of International Business Studies, 29(3), 599-607.

Casson, M., \& Lopes, T. d. S. (2013). Foreign direct investment in high-risk environments: An historical perspective. Business History, 55(3), 375-404.

Click, R. W. (2012). Does foreign investment carry baggage from home? Doctoral dissertation, George Washington University.

Cuervo-Cazurra, A. (2011). Global strategy and global business environment: The direct and indirect influences of the home country on a firm's global strategy. Global Strategy Journal, 1(3-4), 382-386.

Cuervo-Cazurra, A., \& Genc, M. (2008). Transforming disadvantages into advantages: Developing-country MNEs in the least developed countries. Journal of International Business Studies, 39(6), 957-979.

Cuervo-Cazurra, A., Inkpen, A., Musacchio, A., \& Ramaswamy, K. (2014). Governments as owners: Stateowned multinational companies. Journal of International Business Studies, 45(8), 919-942.

Cui, L., \& Jiang, F. (2012). State ownership effect on firms' FDI ownership decisions under institutional pressure: A study of Chinese outward-investing firms. Journal of International Business Studies, 43(3), $264-284$. Darendeli, I. S., \& Hill, T. L. (2016). Uncovering the complex relationships between political risk and MNE firm legitimacy: Insights from Libya. Journal of International Business Studies, 47(1), 68-92.

Desbordes, R. (2010). Global and diplomatic political risks and foreign direct investment. Economics \& Politics, 22(1), 92-125.

Doz, Y. (2011). Qualitative research for international business. Journal of International Business Studies, 42(5), 582-590.

Fitzpatrick, M. (1983). The definition and assessment of political risk in international business: A review of the literature. Academy of Management Review, 8(2), 249-254.

Friedmann, R., \& Kim, J. H. (1988). Political risk and international marketing. Columbia Journal of World Business, 23(4), 63-74.

Gao, L., Liu, X., \& Lioliou, E. (2015). A double-edged sword: The impact of institutions and political relations on the international market expansion of Chinese state-owned enterprises. Journal of Chinese Economic and Business Studies, 13(2), 105-125.

García-Canal, E., \& Guillén, M. F. (2008). Risk and the strategy of foreign location choice in regulated industries. Strategic Management Journal, 29(10), 1097-1115.

Gioia, D. A., Corley, K. G., \& Hamilton, A. L. (2013). Seeking qualitative rigor in inductive research notes on the Gioia methodology. Organizational Research Methods, 16(1), 15-31.

Glaser, B. G., \& Strauss, A. L. (1967). The discovery of grounded theory: Strategies for qualitative research. New York: Aldine.

Globerman, S., \& Shapiro, D. (2009). Economic and strategic considerations surrounding Chinese FDI in the United States. Asia Pacific Journal of Management, 26(1), 163-183. 
Henisz, W. J., \& Zelner, B. A. (2005). Legitimacy, interest group pressures, and change in emergent institutions: The case of foreign investors and host country governments. Academy of Management Review, 30(2), 361-382. Holburn, G. L., \& Zelner, B. A. (2010). Political capabilities, policy risk, and international investment strategy: Evidence from the global electric power generation industry. Strategic Management Journal, 31(12), 1290-1315. Jakobsen, J. (2010). Old problems remain, new ones crop up: Political risk in the $21^{\text {st }}$ century. Business Horizons, 53(5), 481-490.

Jensen, N. (2008). Political risk, democratic institutions, and foreign direct investment. The Journal of Politics, 70(4), 1040-1052.

Jiménez, A., Benito-Osorio, D., \& Palmero-Cámara, C. (2015). Learning from risky environments: global diversification strategies of Spanish MNEs. Management International Review, 55(4), 485-509.

Johansson, J. K., Douglas, S. P., \& Nonaka, I. (1985). Assessing the impact of country of origin on product evaluations: a new methodological perspective. Journal of Marketing Research, 17(3), 388-396.

Knight, F. H. (1921). Risk, Uncertainty and Profit. New York: Hart, Schaffner and Marx.

Kobrin, S. J. (1979). Political risk: A review and reconsideration. Journal of International Business Studies, 10(1), 67-80.

Liesch, P. W., Welch, L. S., \& Buckley, P. J. (2011). Risk and uncertainty in internationalisation and international entrepreneurship studies. Management International Review, 51(6), 851-873.

Liu, X., Buck, T., \& Shu, C. (2005). Chinese economic development, the next stage: Outward FDI? International Business Review, 14(1), 97-115.

Liu, X., Gao, L., Lu, J., \& Lioliou, E. (2016). Environmental risks, localization and the overseas subsidiary performance of MNEs from an emerging economy. Journal of World Business, 51(3), 356-368.

Luo, Y. (2001). Toward a cooperative view of MNC-host government relations: Building blocks and performance implications. Journal of International Business Studies, 32(3), 401-419.

March, J. G., \& Shapira, Z. (1987). Managerial perspectives on risk and risk taking. Management Science, 33(11), 1404-1418.

McKelvie, A., Haynie, J. M., \& Gustavsson, V. (2011). Unpacking the uncertainty construct: Implications for entrepreneurial action. Journal of Business Venturing, 26(3), 273-292.

Meyer, K. E., Ding, Y., Li, J., \& Zhang, H. (2014). Overcoming distrust: How state-owned enterprises adapt their foreign entries to institutional pressures abroad. Journal of International Business Studies, 45(8), 10051028.

Miller, K. D. (1992). A framework for integrated risk management in international business. Journal of International Business Studies, 23(2), 311-331.

Miller, K. D. (2007). Risk and rationality in entrepreneurial processes. Strategic Entrepreneurship Journal, 1(12), 57-74.

Moeller, M., Harvey, M., Griffith, D., \& Richey, G. (2013). The impact of country-of-origin on the acceptance of foreign subsidiaries in host countries: An examination of the 'liability-of-foreignness'. International Business Review, 22(1), 89-99.

Payne, J. W., Bettman, J. R., \& Johnson, E. J. (1993). The Adaptive Decision Maker. Cambridge University Press.

Peng, M. W. (2012). The global strategy of emerging multinationals from China. Global Strategy Journal, 2(2), 97-107.

Quer, D., Claver, E., \& Rienda, L. (2012). Political risk, cultural distance, and outward foreign direct investment: Empirical evidence from large Chinese firms. Asia Pacific Journal of Management, 29(4), 1089-1104.

Robock, S. H. (1971). Political risk: Identification and assessment. Columbia Journal of World Business, JulyAugust, 6-20.

Sarasvathy, S. D. (2001). Causation and effectuation: Toward a theoretical shift from economic inevitability to entrepreneurial contingency. Academy of Management Review, 26(2), 243-263.

Satyanand, P. N. (2010). How BRIC MNEs deal with international political risk. Columbia FDI Perspectives, No.22. May 5, 2010.

Scherer, A. G., Palazzo, G., \& Seidl, D. (2013). Managing legitimacy in complex and heterogeneous environments: Sustainable development in a globalized world. Journal of Management Studies, 50(2), $259-284$. Simon, J. D. (1984). A theoretical perspective on political risk. Journal of International Business Studies, 15(3), 123-143.

Stevens, C. E., Xie, E., \& Peng, M. W. (2015). Toward a legitimacy-based view of political risk: The case of Google and Yahoo in China. Strategic Management Journal, 37(5), 945-963

Williamson, O. E. (1985). The Economic Institutions of Capitalism. Simon and Schuster.

Yaprak, A., \& Sheldon, K. T. (1984). Political risk management in multinational firms: An integrative approach. Management Decision, 22(6), 53-67.

Yin, R. K. (2003). Case study research: Design and methods. (3rd ed). Thousand Oaks, California: Sage. Zelner, B. A., Henisz, W. J., \& Holburn, G. L. (2009). Contentious implementation and retrenchment in 
neoliberal policy reform: The global electric power industry, 1989-2001. Administrative Science Quarterly, 54(3), 379-412. 
Table 1 Sample characteristics

\begin{tabular}{|c|c|c|c|c|c|}
\hline Firm(s) & Interviewee(s) & Industry & Host country(ies) & $\begin{array}{l}\text { Years of } \\
\text { international } \\
\text { operation }\end{array}$ & Ownership \\
\hline A & $\mathrm{A} 1 ; \mathrm{A} 2$ & Aircraft leasing & Ireland & 5 years & SOE \\
\hline $\mathrm{B}$ & B1; B2 & Telecommunication - Operator & Spain; UK & 10 years & SOE \\
\hline $\mathrm{C}$ & $\mathrm{C} 1$ & $\begin{array}{l}\text { Telecommunication - Equipment } \\
\text { provider }\end{array}$ & $\begin{array}{l}\text { Austria, Belgium, Germany, Netherlands, Spain, Sweden, } \\
\text { UK }\end{array}$ & 11 years & Private \\
\hline $\mathrm{D}$ & D1 & Oil prospecting & Angola, Uganda & 11 years & SOE \\
\hline $\mathrm{E}$ & E1 & $\begin{array}{l}\text { Telecommunication - Equipment } \\
\text { provider }\end{array}$ & $\begin{array}{l}\text { Austria, France, Germany, Ireland, Italy, Netherlands, } \\
\text { Sweden, UK }\end{array}$ & 15 years & Private \\
\hline $\mathrm{F}$ & F1; F2 & Real estate; Hospitality & Spain, UK & 5 years & Private \\
\hline G & $\mathrm{G} 1 ; \mathrm{G} 2$ & Agriculture - Dairy & Ireland, Netherlands & 6 years & SOE \\
\hline $\mathrm{H}$ & $\mathrm{H} 1$ & Manufacturing - Infrared camera & Germany, Ireland & 8 years & Private \\
\hline I & $\mathrm{I} 1 ; \mathrm{I} 2$ & Manufacturing - Textile & Egypt & 7 years & Private \\
\hline $\mathrm{J}$ & $\mathrm{J} 1 ; \mathrm{J} 2$ & Manufacturing - Elevator & Egypt & 9 years & Private \\
\hline $\mathrm{K}$ & $\mathrm{K} 1$; K2 & Manufacturing - Personal care & Nigeria; Tanzania & 8 years & Private \\
\hline $\mathrm{L}$ & L1; L2 & Construction & Rwanda; Tanzania; Uganda & 7 years & SOE \\
\hline M & M1; M2 & Construction & Angola; Congo; Mauritius; Poland; Rwanda; Tanzania; UK & 25 years & SOE \\
\hline $\mathrm{N}$ & N1 & Pharmaceutical & Netherlands; South Africa & 20 years & Private \\
\hline $\mathrm{O}$ & $\mathrm{O} 1 ; \mathrm{O} 2$ & Agriculture - Dairy and Beverage & France; UK & 8 years & SOE \\
\hline $\mathrm{P}$ & P1; P2 & Construction & Algeria; Angola; Cameroon; Sudan; Tunisia & 5 years & SOE \\
\hline
\end{tabular}

Sample $=16$ firms 


\section{Fig 1a Political Risks in Developed Countries (EU)}

\section{$1^{\text {st }}$ Order codes}

$2^{\text {nd }}$ Order codes

Aggregated dimensions

- $\quad$ Leakage of strategic assets, resources, and technologies to Chinese MNEs

- Chinese government involvement in business operations

- Chinese MNEs' carriage of political agenda

- Direct financial support through subsidies

- Indirect financial support through cheap loans

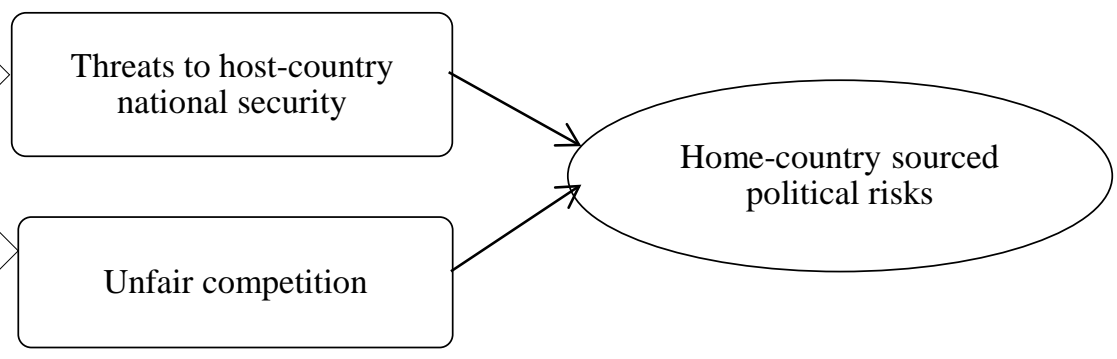

- Regulatory barriers at entry level

- Regulatory barriers at operational level

- Low level of regulatory barriers

- Open competition

- Tense industrial relations with local employees

- Unethical conduct

- Disregard of local history and culture

- Victims of Chinese counterfeit products' / poor reputation

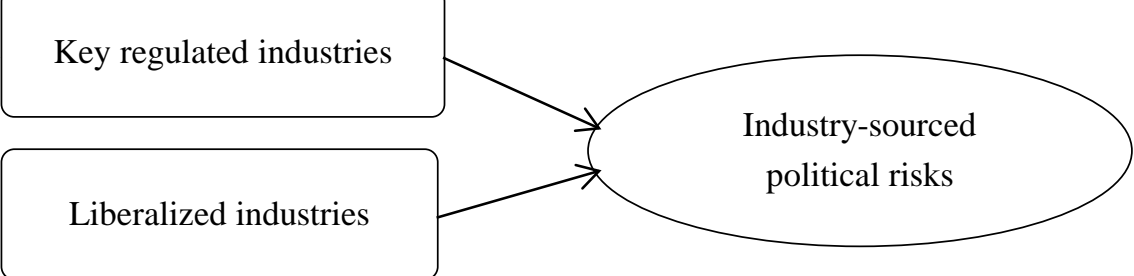

Negative local government attitude

Firm-behaviour sourced

Negative local public attitude political risks 
Fig 1b Political Risks in Developing Countries (Africa)

\begin{tabular}{lll}
$1^{\text {st }}$ Order codes & $2^{\text {nd }}$ Order codes & Aggregated dimensions \\
\hline
\end{tabular}

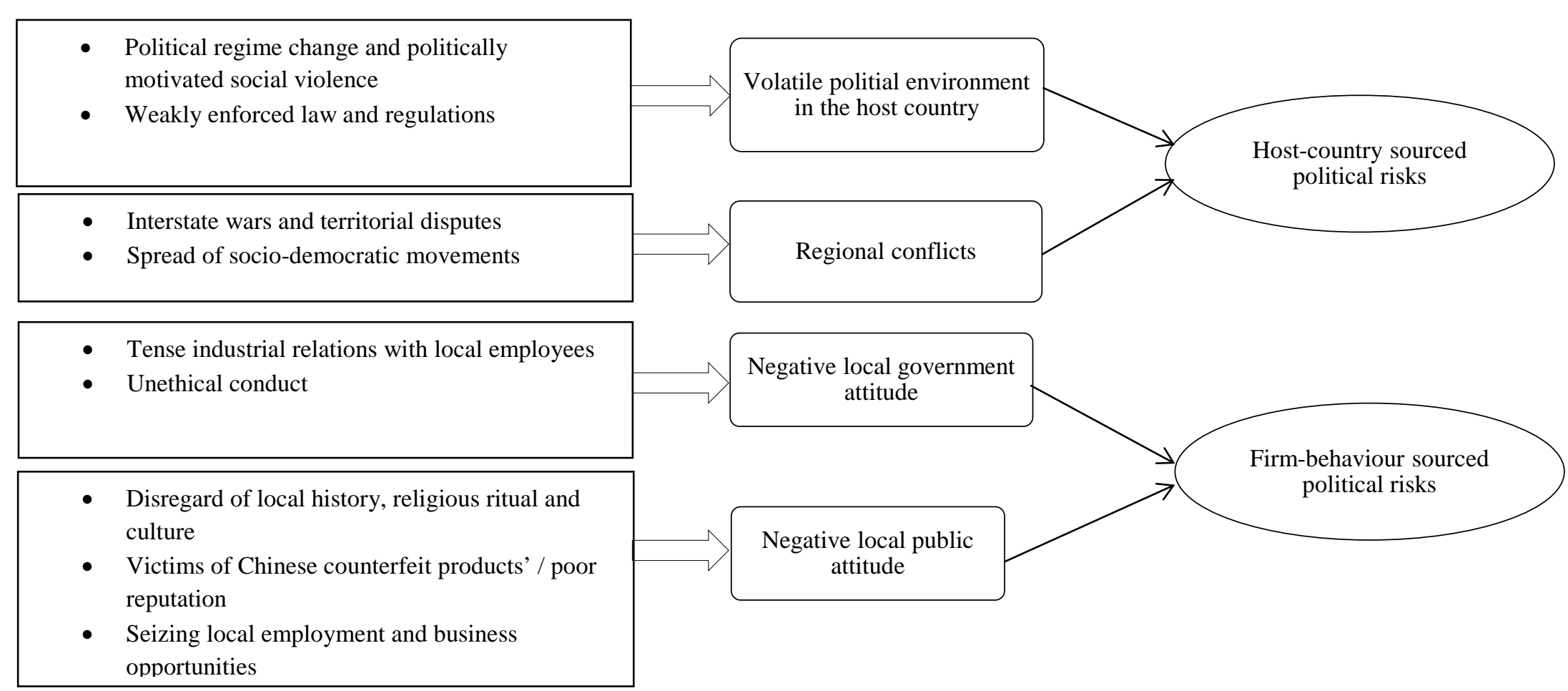

